\title{
TREPANATION AND ENLARGED PARIETAL FORAMEN ON SKULLS FROM THE LOYALTY ISLANDS (MELANESIA)
}

\author{
TREPANACIJA I POVEĆAN PARIJETALNI \\ FORAMEN NA LUBANJAMA OTKRIVENIMA \\ NA OTOČJU LOYALTY
}

\author{
Sergey V. Vasilyev", Alexey A. Sviridov*
}

\begin{abstract}
SuMMARY
The goal of this study is a comprehensive examination of openings discovered on two skulls in the collection of skeletal remains from the Loyalty Islands (Melanesia). The skull № 1524 displayed an evidence of successful trepanation, and the skull № 7985 revealed openings that were reminiscent of a trepanation, however, we are inclined to believe that in the latter case we are dealing with a rare genetic anomaly - enlarged parietal foramen.
\end{abstract}

Key words: Osteoarchaeology; trepanation; skull; enlarged parietal foramen; Loyalty Islands.

\section{INTRODUCTION}

Trepanation is one of the most ancient surgical procedures known to mankind. Over the course of thousands of years, traditional societies have developed methods allowing this complex procedure to be successful in $50-$ $78 \%$ of cases. Meanwhile, in the European medicine of the $18-19^{\text {th }}$ centuries

Institute of Ethnology and Anthropology Russian Academy of Science, Centre of Physical Anthropology, Moscow, Russia.

Correspondence address: Sergey V. Vasilyev, Institute of Ethnology and Anthropology

Russian Academy of Science, Centre of Physical Anthropology, Leninsky prospect 32A, Moscow 119334, Russia.E-mail: vasbor1@yandex.ru. 
mortality caused by such operations varied from 50 to roo\% (Mednikova, 200I).

Our study aims at description and assessment of openings found on a series of skulls from the Loyalty Islands. The Loyalty Islands are situated in the Pacific Ocean, in the southern part of Melanesia, east from the large island of New Caledonia.

\section{Material}

We have examined 68 skulls from the Loyalty Islands stored in the Musée de l'Homme in Paris. Most of these skulls were collected during the second half of the $19^{\text {th }}$ century, when the Loyalty Islands were a French colony. Additional skulls have been found subsequently during archaeological excavations in 'burial caves'.

Before the French occupation, the islanders left dead bodies wrapped in mats in caves and natural cracks closest to their houses. M. Bonnafont, who visited the islands in 1869 , noted that the microclimate in those caves facilitated mummification of the remains (Bonnafont, I87I). The examined skeletal collection probably dates back to the $18-19^{\text {th }}$ centuries. While examining this collection, we found two cases with openings in the skull.

\section{RESUlts AND DISCUSSION}

The skull № 1524, from the Island of Lifou, belonged to a male aged 20-25 years. A trepanation opening was situated on the left-hand side of the squama occipitalis, covering a section of the lambdoid suture and the adjacent small section of the left squama occipitalis. The opening was irregular oval in shape, with slight widening at the top. The outside and inside diameters of the opening were $53 \times 4$ I and $46 \times 34$ $\mathrm{mm}$, respectively. The edges of the opening were completely healed, the diploe structure was not detected and the osteotylus was completely formed (Figure I, 2).

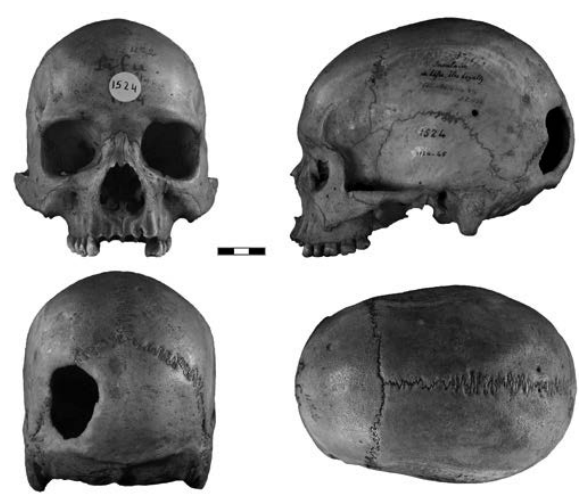

Figure r: Trepanation on the Skull I524. 
The shape and the nature of the opening suggest that it was made by the scraping method as described by F.P. Lisovsky (Mednikova, 200I).

Some healed inflammatory tissues of round shape with the diameter of 5-IO $\mathrm{mm}$ were found on the surface of the squama occipitalis and squama parietalis around the trepanation opening. Localization of these tissues around the opening suggests their interconnection, but it was not possible to determine whether they relate to the trauma that led to trepanation or to complications after the surgical procedure.

The skull № 7985, also from the Island of Lifou, belonged to a male aged 20-25 years. The skull had one opening on each parietal bone near nutrient foramena of the obelion (the rear third of the saggital suture). The openings were round in shape. The outside diameter was much larger than the inside: 30 $\mathrm{mm}$ and io $\mathrm{mm}$, respectively, for the opening on the left parietal bone and $25 \mathrm{~mm}$ and $8.5 \mathrm{~mm}$, respectively, for

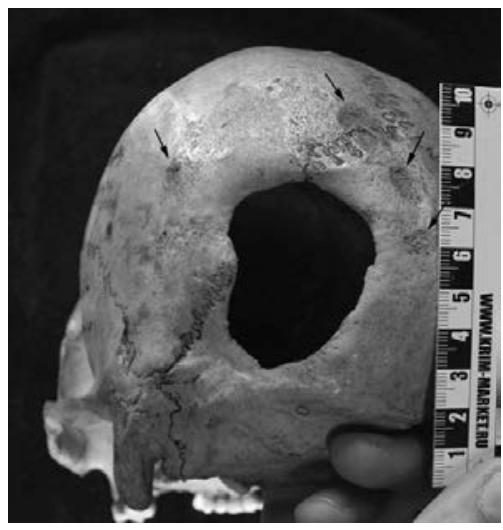

Figure 2: Trepanation on the skull 5524 . The increase.

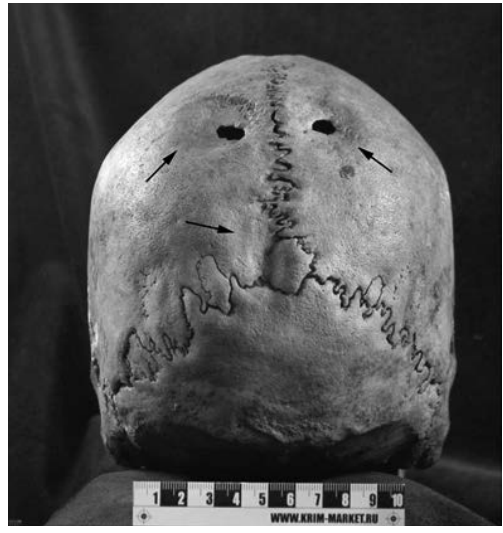

Figure 3: Enlarged parietal foramen on the skull 7985 . the opening on the right parietal bone. Edges of the openings were smoothed, a structure of the spongy tissue was modified and shows traces of osteotylus formation. Some sections had a full-fledged osteotylus (Figure 3, 4).

While the openings found on the skull № 7985

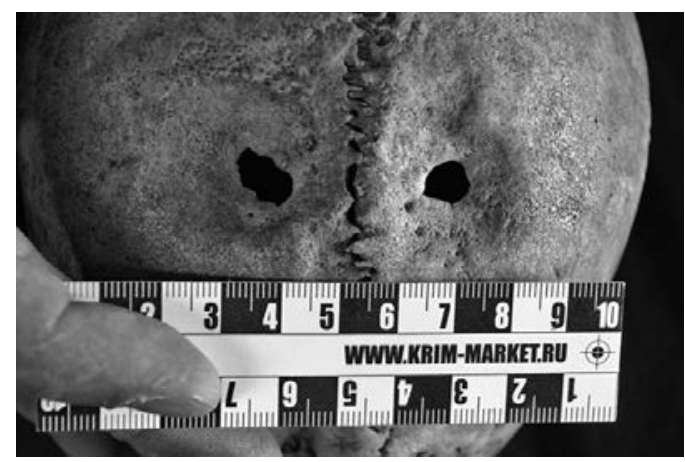

Figure 4: Enlarged parietal foramen on the skull 7985. The increase. 
were also reminiscent of a trepanation, we are inclined to believe that in this case we are dealing with a rare genetic anomaly- enlarged parietal foramen. In the literature this phenomenon is also referred to as fenestrae parietales symmetricae, foramina parietalia permagna, or giant parietal foramina (Christoph, 2013).

We also found a blow mark near the lambda, a little closer to the left parietal bone. The trauma resulted in a slight dislocation of an insert ossicle near the lambda and formation of a recess on the parietal bone. It is quite likely that the trauma was connected with faster suture closure with the insert ossicle and the left parietal bone, while the suture with the right parietal bone remained open.

Due to the records kept in London hospitals, we were able to obtain some information about mortality rates caused by trepanations conducted there for medical reasons (they were mostly connected to the head injuries). In general, trepanations were a rare procedure: over the course of eight years in the 1870 , there were recorded only 86 cases of such operations-about II per year. Mortality caused by trepanations was very high in the range of $75-78 \%$ (Graham, 2003).

At the same time, during the second half of the $19^{\text {th }}$ century, the Tolai tribe, that lived in the south-western part of the Pacific Ocean on the Island of New Britain (east from New Guinea) and did not use any metal tools, achieved $75 \%$ success rate, thus by far exceeding that experienced by the western medicine at the time (Graham, 2003).

The main reason for trepanation was fracture of the cranium that required urgent extraction of splinters and prevention of cerebral edema. E. Hadfield asserts that the main cause of trepanation on the island of Ouvéa (one of the Loyalty Islands) was a special type of headache that could not be healed with the use of other methods (Hadfield, I920). However, local doctors could also decide to conduct trepanation to treat other syndromes such as epilepsy, depression or just general unwellness (Graham, 2003).

Trepanations on various islands of Melanesia were conducted with the use of the following tools: shark teeth, obsidian flakes, batwing bones, split bamboo sticks or sharp fragments of sea-shells (Watters, 2007).

Wounds were then cleaned with the juice of green coconut, which was also used for washing off surgeons' hands. Skin incisions could be longitudinal, V or Y-shaped (Watters, 2007), and X-shaped (Hadfield, 1920). After the incision was made, two assistants pulled back the skin using rattan ropes 
tied to a patient's hair. In case of a skull fracture, the surgeon first removed large bone fragments and then smaller splinters (Watters, 2007). Cranium bones were then cut through with obsidian flakes. If a patient fainted, the surgeon waited until they recovered consciousness and then continued. The operation left a smooth opening of round or oval shape. The skin incisions were stitched together with needles made of batwing bones and threads made of coconut or rattan filaments. The entire surgery lasted only about an hour (Hadfield, I920).

After the operation, the wound was cleaned with coconut juice and the hair around it was shaved. The head was dressed with a bandage made of internal layer of bark or banana leaves dried on hot coals. The trepanation area was dressed with a protective rattan net. The bandage was changed every 5-6 days (Watters, 2007). Complete recovery usually required 2-3 weeks. According to E. Hadfield, a I2-year-old boy, who underwent trepanation, was able to return home on his own being assisted only by his mother. Later on, the researcher had a possibility to follow up the fate of this young patient. She writes that the child did not show any mental abnormalities, did well in studies, learned several languages and afterwards became one of the best pastors in New Caledonia (Hadfield, I920).

The operation also involved manipulation of magical amulets for achieving the 'true recovery' (Watters, 2007).

The practice of trepanation was quite widespread in Melanesia down to the World War II, but in the second half of the $20^{\text {th }}$ century such cases became very rare. In the I980s most of inhabitants of New Britain did not even remember that their ancestors had been able to perform such surgery (Graham, 2003).

Graham Martin, a scholar from New Zealand, tried to explain why trepanations in Melanesia had been more successful than those in the $19^{\text {th }}$ century Europe. He has suggested the following factors:

- The use of disposable tools reduced the risk of infections.

- Operations were not performed in the hospitals, in which infections were normally quite frequent, but in an open area.

- Wounds were cleaned with sterile coconut juice, bandages were made of fresh leaves, skin was stitched together with coconut filaments and with the use of needles made of batwing bones. Thus, all the materials bore bacteria that were already adapted for this particular environment and did not germinate in patients' wounds (Graham, 2003). 


\section{Conclusion}

Both skulls with openings belonged to young males aged $20-25$ years. The skull № 1524 displayed an evidence of successful trepanation, while the openings on the skull № 7985 appeared to be more consistent with a rare genetic anomaly known as enlarged parietal foramen.

\section{Acknowledgements.}

We would like to thank Philippe Mennecier, the curator of anthropological collections of the Musée de l'Homme in Paris, for research support and friendly attitude to us.

\section{REFERENCES}

1. Bonnafont M. Des sépultures aux îles Loyalty // Bulletins de la Société d'anthropologie de Paris. 1871. II Série, tome 6, pp. 236-240.

2. Christoph J. Griessenauer, Philip Veith at all. Enlarged parietal foramina: a review of genetics, prognosis, radiology, and treatment. // Childs Nerv Syst. 2013 Vol. 29. pp. 543-547.

3. Graham M. Why Trepan? Contributions from Medical History and the South Pacific.Chapter 23.In:Breitwieser R., ArnottR., Finger S., Smith C. Trepanation: History, Discovery, Theory (Studies on Neuropsychology, Development, and Cognition), 2003, Swets \& Zeitlinger B.V., Lisse, The Netherlands, pp. 338-340.

4. Hadfield E. Among the natives of the Loyalty group. London, Macmillan, 1920. pp. 198-199.

5. Mednikova M.B. Trepanatsii u drevnikh narodov Evrazii. Moscow, Nauchnyi Mir, 2001, p. 364 [in Russian]

6. Watters David A. K. Skull trepanation in the Bismarck Archipelago // Papua New Guinea Medical Journal, 2007. Mar-Jun; 50(1-2), pp. 20-24.

\section{SAŽETAK}

Cilj je ovog istraživanja opsežan pregled otvora otkrivenih na dvjema lubanjama u zbirci skeletnih ostataka s otočja Loyalty (Melanezija). Lubanja br. 1524 dokaz je uspješne trepanacije, a otvori lubanje br. 7985 podsjećaju na trepanaciju, međutim skloni smo vjerovati da se u potonjem slučaju susrećemo s rijetkom genetskom anomalijom - povećanim parijetalnim foramenom.

Ključne riječi: osteoarheologija; trepanacija; lubanja; povećani parijetalni foramen; otočje Loyalty. 